International Journal of Advanced Geosciences, $9(1)(2021) 5-10$
International Journal of Advanced Geosciences
SPC
Website: $w w w$. sciencepubco.com/index.php/IJAG
Research paper

\title{
Lithological attributes of hd-001 well, shallow offshore, Niger delta basin, Nigeria
}

\author{
Olubusayo A. Olatunji ${ }^{1}$ *, Edward A. Okosun ${ }^{2}$, Usman S. Onoduku ${ }^{2}$, And Yahya B. Alkali ${ }^{2}$ \\ ${ }^{1}$ Department of Earth Sciences, Faculty of Science, Adekunle Ajasin University, Akungba-Akoko, Ondo State, Nigeria \\ ${ }^{2}$ Department of Geology, Faculty of Physical Sciences, Federal University of Technology, Minna, Niger State, Nigeria \\ *Corresponding author E-mail: olubusayo.olatunji@aaua.edu.ng
}

\begin{abstract}
Lithological analysis was carried out on 96 ditch cuttings samples from HD-001 well located within the shallow offshore Niger delta basin, Nigeria. Three lithofacies sequences were delineated by the integration of wireline logs textural/lithologic attritudes and the distribution of index accessory minerals. They are transitional paralic, paralic and marine paralic sequences. The lithologic, textural and wireline log data indicate that the entire interval studied in the HD-001 well belongs to the Agbada Formation. The Formation is made up of alternating sand and shale units which suggests rapid shoreline progradation. The grain size increases from essentially fine to mediumgrained at the basal part of the well to dominantly coarser grain at the upper part. The index accessories recognize shallow marine to coastal deltaic settings environment of deposition. Sand bodies which represent sub-environments within those settings are deposited in sequences. Each sequence begins with a transgressive phase followed by significant regressions.
\end{abstract}

Keywords: Ditch Cuttings; Formation; Index Accessory; Lithofacies; Niger Delta.

\section{Introduction}

The Niger delta basin covers a territorial area of about 140,000 sq.km in the continental margin of the Gulf of Guinea on the coast of west Africa (Obaje, 2009). It lies between Latitudes $4^{\circ}$ and $6^{\circ} \mathrm{N}$ and Longitudes $3^{\circ}$ and $6^{\circ} \mathrm{E}$ in the southern part of Nigeria (Ojo et al., 2009). Evamy et al. (1978), Ejedawe (1981), Knox and Omatsola (1987) and Stacher (1995) explained that the evolution of the delta is controlled by pre- and synsedimentary tectonics. Some factors that also controlled the growth of the delta are climatic changes and the proximity and type of sediment source areas. During the Cenozoic, until the Middle Miocene, the Niger delta evolved through stages of sedimentation over an oceanward-dipping continental basement into the Gulf of Guinea (Reijers, 2011). After this, progradation happened over a landward dipping oceanic basement. An overall regressive, offlapping sediments succession of about 1200 meters thickness resulted that is made up of three diachronous siliciclastic units: the deep marine pro-delta Akata Formation, the shallow marine delta front Agbada Formation and the continental, delta-top Benin Formation.

The Niger delta is the most important and studied sedimentary basin in Nigeria in terms of sediments' size and thickness and economic viewpoint as its crude oil reserves remain a source of income for the country. This study is aimed at analyzing the lithofacies sequences penetrated by HD-001 well and to describe the lithological attributes of the sequences interpreted using ditch cuttings, wireline logs, textural/lithological characteristics and the distribution of index accessories such as ferruginous materials, carbonaceous fragments and mica flakes.

\section{Study area}

The study area lies in the Niger delta basin within latitudes $4^{\circ} 5^{\prime} 59.6^{\prime \prime} \mathrm{N}$ and longitudes $6^{\circ} 24^{\prime} 28.6^{\prime \prime} \mathrm{E}$ within the shallow offshore area, western Niger delta, Nigeria. The name of the well has been coded well HD-001 by Shell Production and Development Company due to proprietary reasons Figure 1 shows the location of the well. 


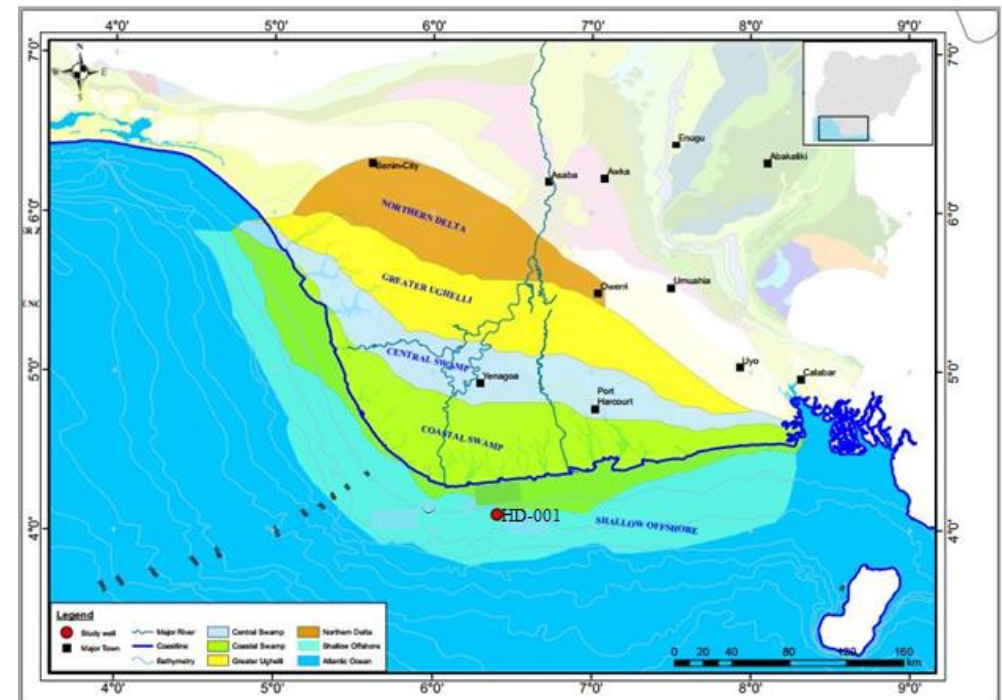

Fig. 1: Location of HD-001 Well, Shallow Offshore Depobelt, Niger Delta, Nigeria (Modified From Samuel, 2009; Oluwajana, 2019).

\section{Materials and methods}

The lithologic descriptions of the sedimentary successions of HD-001 well was done mainly by studying the gamma ray log signatures, physical examination of ditch cuttings samples and microscopic analysis of the washed samples.

\subsection{Lithologic description}

The lithologic description was carried out by the physical examination of the samples. Fissile samples were denoted to be shale while fine to coarse grained samples are the sandstones. Gamma ray logs were also employed in describing the lithologies because high and low values of gamma ray indicate shale and sandstone lithologies respectively (Olayiwola and Bamford, 2016). The fining and coarsening upward signatures of the gamma ray patterns description by Sneider et al. (1978) and Beka and Oti (1995) and Onyekuru et al., (2012) were employed in this study (Figure 2 and 3). Funnel-shaped log patterns signify a coarsening upward trend and decreasing clay contents up section.

DELTAIC CHANNEL DEPOSITS
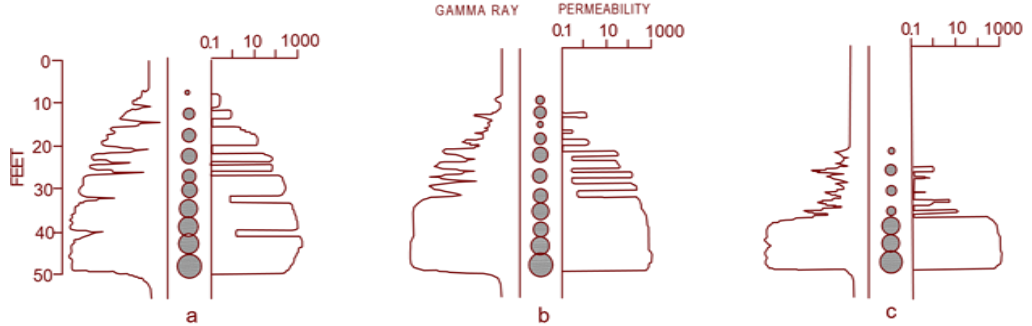

DELTAIC BAR DEPOSITS
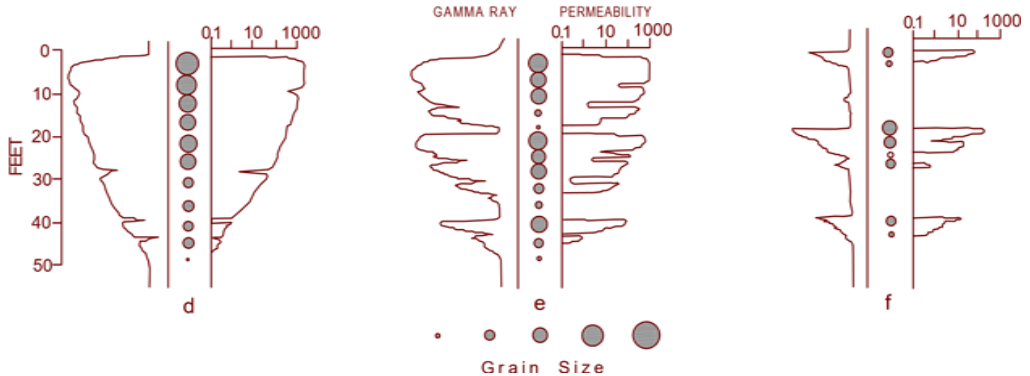

Fig. 2: Typical Log Responses and Permeability Profiles of Deltaic Deposits (Sneider Et Al., 1978). 

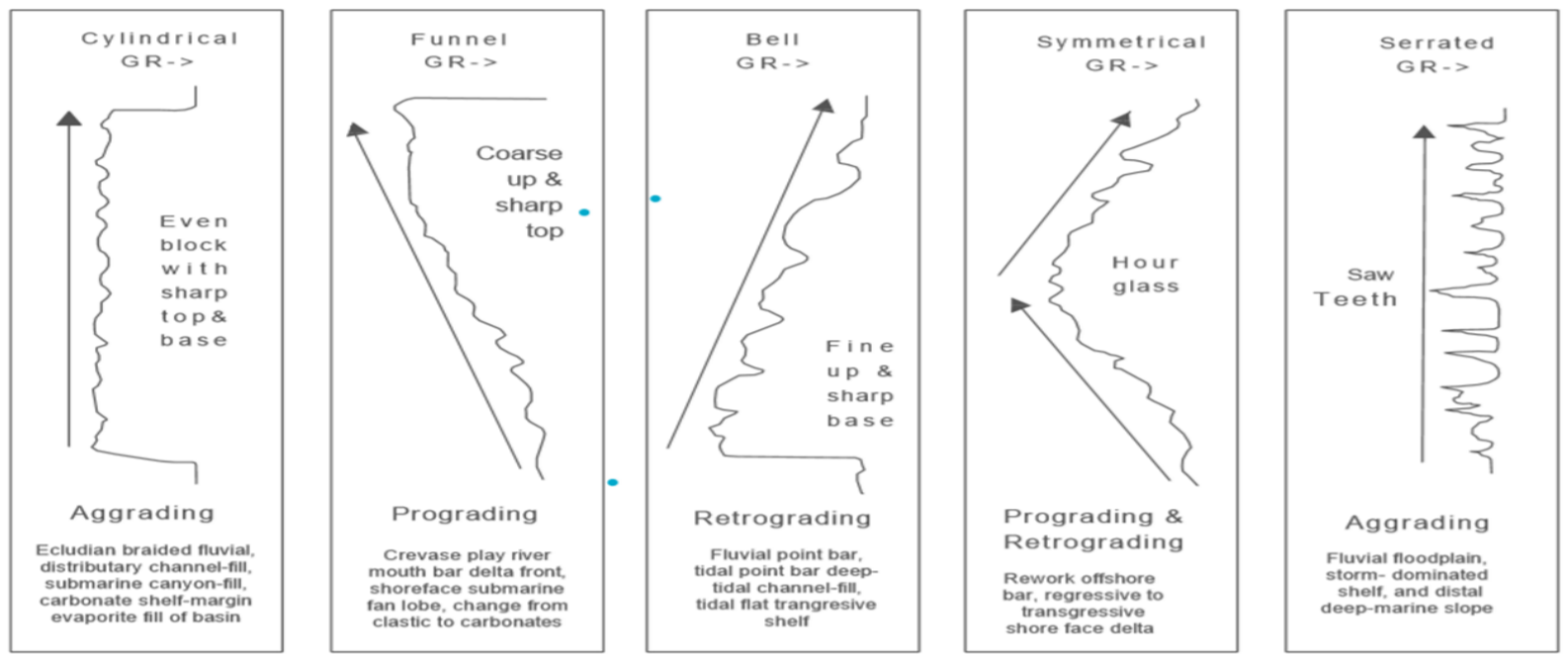

Fig. 3: Different Well Log Signatures for Different Environments (Beka and Oti, 1995; Onyekuru Et Al., 2012)

\section{Results and discussions}

Sedimentological deductions are based on the integrations of wireline log signatures, textural/lithological attributes and distribution of index accessory minerals. These permitted the assignment of the entire study section (4875 - $12090 \mathrm{ft})$ of HD-001 well of the Agbada Formation. These criteria enabled the recognition of three lithofacies sequences; The marine paralic, paralic and transitional paralic lithofacies sequences within the section. (Table 1).

Detailed lithologic description of the studied well is graphically depicted in Figure 4.

Table 1: Lithostratigraphic Subdivision of HD-001 Well

\begin{tabular}{|c|c|c|c|}
\hline Interval $(\mathrm{ft})$ & Formation & Lithofacies Sequence & Lithological Characteristic \\
\hline $\begin{array}{l}4,875- \\
6,700\end{array}$ & & $\begin{array}{l}\text { TRANSITIONAL } \\
\text { PARALIC }\end{array}$ & $\begin{array}{l}\text {-Predominantly sands with relatively thick shale intercalations. } \\
\text {-Sands are predominantly quartzose, slightly feldsparthic, fine to medium - grained, occasional- } \\
\text { ly coarse to very coarse - grained and granular. } \\
\text {-Sands are moderately to poorly sorted } \\
\text {-Sand/ Shale ratio of approximately } 70: 30 \text {. }\end{array}$ \\
\hline $\begin{array}{l}10,850- \\
12090\end{array}$ & AGBADA & MARINE PARALIC & $\begin{array}{l}\text {-Predominantly shale with relatively thick sand intercalations. } \\
\text {-Sands are quartzose, fine to medium, occasionally coarse to very coarse-grained and granular. } \\
\text { Sands are poorly to well sorted. } \\
\text {-Sand/ Shale ratio of approximately } 30: 70 \text {. }\end{array}$ \\
\hline
\end{tabular}




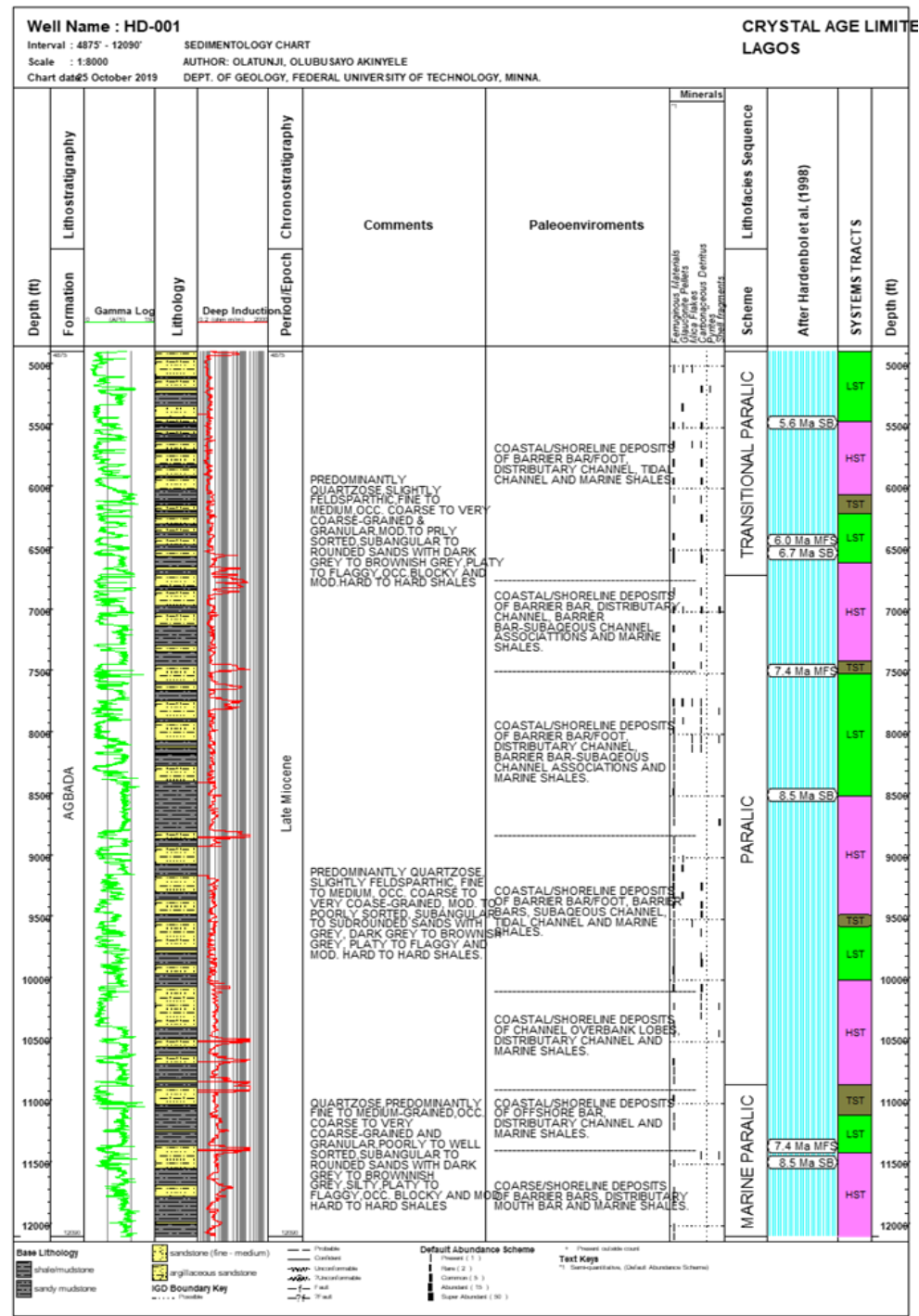

Fig. 4: Sedimentologic Chart of HD-001 Well.

\subsection{Marine paralic/paralic lithofacies sequence of HD-001 well $(12,090-6,700 \mathrm{ft})$}

This interval is mainly a heterogeneous sequence of alternating sand and shale/ siltstone units. The regular pattern of sand and shale/siltstone intercalations allows easy recognition on gamma ray logs of six hallocycles (third-order cycles) or subcycles of sedimentation within the marine paralic -and paralic sequences. Each of these subcycles commences with a relatively thick marine shale/silt and progressively shallows into fluviomarine /fluviatile sands. The recognized subcycles are as summarized in Table 2 and discussed as follows.

Table 2: Lithofacies Subcycles of HD-001 Well Marine Paralic/ Paralic Sequence

\begin{tabular}{llll}
\hline Lithofacies sequence & Subcycles & Depth interval (ft) & Thickness (ft) \\
\hline & F & $6700-7440$ & 740 \\
Paralic & E & $7440-8780$ & 1340 \\
& D & $8780-10050$ & 1270 \\
Marine Paralic & C & $10050-10850$ & 800 \\
& B & $10850-11350$ & 500 \\
& A & $11350-12090$ & 740 \\
\hline
\end{tabular}

\subsection{The marine paralic lithofacies sequence $(12090-10850 \mathrm{ft})$}

The marine paralic lithofacies sequence is characterized by thinner shale units. The sand/ shale ratio is approximately 30:70. Two (2) depositional hallocycles (subcycles A and B, Table 2) were identified. Each hallocycles consists of underlying predominantly shaly (transgressive) phase, overlain by a thick sandy (regressive) phase. These hallocycles are:

i). $\quad$ Subcycle A: $(12,090-11,350 \mathrm{ft})$

This is the lowermost section of the analyzed interval and is composed of a thick shale unit $(12,090-11,550 \mathrm{ft})$ with silty sand intercalations, overlain by a stack of sands $(11,550-11,350 \mathrm{ft})$.

The shale is dark grey to brownish grey, silty, platy to flaggy, occasionally blocky and moderately hard to hard. The sands are milky white, quartzose, fine to medium- grained, occasionally coarse-grained to very coarse-grained and granular, poorly to well sorted and sub-angular to rounded Rare ferruginous materials occur almost throughout the sub-cycle with spotty records of mica flakes and shell fragments at sample interval $11415 \mathrm{ft}$. 
The predominantly shaly/ silty character of the lower part of the sub-cycle and the presence of ferruginous materials suggest deposition in a low energy, oxic, shallow marine settings (Selley, 1978). The subtle upward coarsening grain size profiles occurring over intervals $12010-11980$ and $11800-11700 \mathrm{ft}$ are most likely to be of barrier bar origin.

At the upper section of the subcycle $(11550-11350 \mathrm{ft})$ consisting of stack of sands characterized by coarsening upward profiles interpreted as distributary mouth bar build-ups, indicate prograding shoreline. Supporting these deductions are the co-occurrence of mica flakes, shell fragments and absence of glauconite pellets.

ii). Subcycle B $(11350-10850 \mathrm{ft})$

This subcycle commences with a silty shale $(11350-11000 \mathrm{ft})$ with thin sand intercalations, overlain by a sandy section $(11000-10850$ $\mathrm{ft}$ ). It constitutes the top of the marine paralic lithofacies sequence.

The shale is dark grey to brownish grey, silty, platy to flaggy and moderately hard to hard. The sands are milky white, predominantly fine to medium - grained, occasionally coarse/ very coarse - grained, sub-angular to sub-rounded and -moderately to well sorted.

Rare/ few ferruginous materials occur almost throughout the sub-cycle. The predominantly shaly/ silty character of the lower section of the sub-cycle and the occurrence of ferruginous materials are consistent with low energy, oxic, shallow marine settings. The symmetrical sands occurring over intervals $11240-11230 \mathrm{ft}$ within the shale is most probably an offshore bar deposit (Sneider et al., 1978)

The sand units of the upper section $(11000-10850 \mathrm{ft})$ characterized by multiserrate cylinder-shaped motifs are most probably distributary channel deposits of the lower deltaic plain. It suggests intermittent high energy burst into the depositional basin. This may also explain the presence of ferruginous materials in the subcycle.

\subsection{The paralic lithofacies sequence $(10850-6700 \mathrm{ft})$}

This lithofacies unit directly overlies the marine paralic sequence. These consist predominantly of well-developed thick sands with relatively thick shaly intervals. (Table 2 and Figure 4). Four (4) depositional subcycles were differentiated within this sequence. These are: i). $\quad$ Subcycle C $(10050-10850 \mathrm{ft})$

This sub-cycle is composed of shaly section $(10850-10380 \mathrm{ft})$ with silty sand intercalations at the base, overlain by a sandy interval $(10380-10050 \mathrm{ft})$.

The shale is grey, dark grey to brownish grey, silty, platy to flaggy and moderately hard to hard. The sands are quartzose, fine to medium - grained, occasionally coarse to very coarse - grained, moderately sorted and sub-angular to sub-rounded. Ferruginous materials, carbonaceous detritus and shell fragments characterized the sequence. Two genetic sand units exhibit cresentric -shaped profile over the intervals $10680-10620 \mathrm{ft}$ and 10510 - $10470 \mathrm{ft}$ and are most probably channel overbank lobes.

While the upper section of the subcycle $(10380-10050 \mathrm{ft})$ consisting of sands characterized by multiserrate cylinder character is interpreted as distributary channel deposits. This is further confirmed by the mixture of carbonaceous detritus, shell fragments and absence of glauconite pellets (Selley, 1976).

ii). Subcycle D: $(10050-8780 \mathrm{ft})$

This subcycle is composed of a thin shale unit $(10050-9800 \mathrm{ft})$ with minor sand intercalations, overlain by a predominantly sandy section $(9800-8780 \mathrm{ft})$.

The sands are milky white, fine to medium-grained, occasionally coarse to very coarse to very coarse-grained, moderately to well sorted and sub-angular to sub -rounded. The shale is dark grey to grey, silty, platy to flaggy and moderately hard to hard.

Index minerals are dominated by ferruginous materials, carbonaceous detritus and glauconite pellets. The coarsening upward sand occurring over interval 9950 - $9900 \mathrm{ft}$ within the shale is most probably a barrier bar/ foot origin.

The aforementioned evidence coupled with the log character of the sand at the upper section $(9800-8780 \mathrm{ft})$ suggest that the multiserrate upward coarsening, cylinder and fining upward profiles are most likely barrier bars, subaqeous channel and tidal channel deposits (prograding complex). Sediments of this sub-cycle are believed to have been laid down in coastal deltaic to inner shelf environments (Sneider et al., 1978).

iii). Subcycle E $(8780-7440 \mathrm{ft})$

This interval is composed of alternating beds of sand and shale with a shaly lower section $(8780-8370 \mathrm{ft})$, overlain by a predominantly sandy sequence $(8370-7440 \mathrm{ft})$.

The shale is grey, dark grey to brownish grey, platy to flaggy and moderately hard to hard. The sands are predominantly quartzose, slightly feldsparthic, fine to medium - grained, occasionally coarse to very coarse - grained and granular, moderately to poorly sorted and sub-angular to round.

Mica flakes and glauconite pellets are spotty while ferruginous materials and carbonaceous detritus occur in rare to few quantities. Rare shell fragments are noted over the upper section of the sub-cycle $(8080-7440 \mathrm{ft})$. The predominantly shaly character of the lower section coupled with presence of glauconite pellets indicate deposition in low energy marine settings in close proximity to the ancient shoreline (Selley, 1978).

The gamma ray log motifs of the upper section of this sub-cycle $(8370-7440 \mathrm{ft})$ are essentially coarsening upwards, cylinders and coarsening upwards on cylinder -shaped profiles interpreted as barrier bar/ foot, distributary channel and barrier bar- subaqeous channel associations. This suggest intermittent high energy clastic burst into the depositional basin. The appearance of shell fragments may also suggest an in-filling of the channel to shallower depth.

iv). Subcycle F $(7440-6700 \mathrm{ft})$

This short subcycle have striking resemblance in log motifs and lithologic attributes with the subcycle E discussed above. Characteristically, it is composed of alternating beds of sands and shales with a shaly lower section $(7440-7110 \mathrm{ft})$ with minor sand breaks, overlain by a predominantly sandy sequence $(7110-6700 \mathrm{ft})$. Index minerals and accessories are mostly ferruginous materials, carbonaceous detritus with spot occurrences of shell fragments and glauconite pellets noted at depth interval $6990 \mathrm{ft}$. These criteria indicate deposition in the lower deltaic plain environment. The amplified sand unit occurring over the interval $7330-7260 \mathrm{ft}$ exhibiting a subtle upward coarsening grain size profile is most probably of barrier bar origin.

The typical cylinder, funnel-cylinder shaped log character coupled with the persistence of ferruginous materials, carbonaceous detritus shell fragment and glauconite pellets in the upper part of the subcycle may suggest a distributary channel, barrier bar-subaqeous channel associations for these sands. The appearance of shell fragments towards the top of this subcycle could be attributed to shallowing of the environment from bottom to the top (Selley, 1978).

\subsection{The transitional paralic lithofacies sequence $(6700-4875 \mathrm{ft})$}


This lithofacies sequence is characterized by frequent sand/ shale alternations with the sand bodies being generally thicker than the shale units. The thickness of the sands ranges from $10-180 \mathrm{ft}$ and the shale intercalation less than $100 \mathrm{ft}$. The sequence exhibit a sand/ shale ratio of approximately of 70:30. Over the upper section of the sequence (4875 - 5940 ft), the sands are predominantly quartzose, slightly feldsparthic; fine to medium; occasionally coarse to granule-sized and moderately to poorly sorted. The lower interval (5940 - $6700 \mathrm{ft})$ is dominated by fine to medium, occasionally coarse to very coarse-grained sands. The shale is grey, dark grey to brownish grey, platy to flaggy, occasionally blocky and moderately hard to hard. Rare to abundant carbonaceous detritus, rare to common ferruginous materials are noted throughout the sequence. Glauconite pellets occur in rare to few quantities over the interval $5490-4875 \mathrm{ft}$ with occasional occurrences of mica flakes and pyrites.

The sand/shale alternation of the sequence suggest frequent interchanging high and low depositional energy regimes which might have resulted from a frequently shifting depositional axis on a gently subsiding passive continental margin. However, the higher proportion of sand and the ubiquitous occurrence of carbonaceous detritus suggest that it was deposited under a generally higher energy regime than the underlying paralic sequence and definitely represent an environment proximal to the underlying paralic/ marine paralic Sequence within a general deltaic environment (Selley, 1978).

The log characters of the sands are essentially funnel, cylinder and minor bell-shaped motifs. This coupled with the presence of carbonaceous detritus and glauconite pellets suggest deposition in the lower deltaic sub-environment varying from barrier bars/ foot, distributary channels and tidal channel. The shale interbeds represent backswamp deposits (interdistributary prodelta deposits).

Also the absence of shell fragment and the spot occurrence of pyrite may indicate that the depositional environment slightly deepens from base to top.

\section{Conclusion}

Lithological analysis was carried out on 96 ditch cuttings samples from HD-001 well located within the shallow offshore Niger delta basin, Nigeria. The integration of sedimentological description of ditch cuttings samples with wireline logs allowed the delineation of three lithofacies sequences; the transitional paralic sequence $(4875-6700 \mathrm{ft})$, the paralic sequence $(6700-10850 \mathrm{ft})$ and the marine paralic sequence (10850 -12090 ft) within the Agbada Formation. The regular pattern of sand and shale/mudstone intercalation permits easy recognition on $\log$ of six subcycles of sedimentation in an extensively developed marine paralic/paralic sequences. Rapid sedimentation rates are inferred on the basis of thick marine paralic/paralic, and transitional paralic section. The index accessory minerals associated with shallow water environments include ferruginous materials, carbonaceous detritus and shell fragments. They occur almost throughout the well section with intermittent deeper water conditions containing glauconite pellets and mica flakes. Pyrites is conspicuously absent. Seismic approach is recommended for the concept of cyclicity to be better understood, for with it, shale markers are easily delineated.

\section{Acknowledgement}

The authors appreciate Mr. Lazarus and the entire staff of Crystal Age Limited, Lagos for their support during the laboratory analysis of this study. Also, special thanks to Dr. Peter Osterloff of Shell Petroleum Development Company, Nigeria for providing some research materials for this paper.

\section{References}

[1] Obaje NG (2009). Geology and Mineral Resources of Nigeria. Springer-Verlag, Berlin Heldelberg. 2000,109 - 113. https://doi.org/10.1007/978-3540-92685-6.

[2] Ojo EA, Fadiya LS and Ehinola OA (2009). Biozonation and correlation of BDX-1 abd BDX-1 wells of deep offshore Niger Delta using calcareous nannofossils. Search and Discovery Article, Association of American Petroleum Geologist. 2009;50194:8. https://doi.org/10.1306/C1EA47ED16C9-11D7-8645000102C1865D.

[3] Evamy, BD, Haremboure, J, Kemerling, WA, Molloy, FA. and Rowlands, PH. (1978). Hydrocarbon habitat of Tertiary Niger Delta, American Association of Petroleum Geologists Bulletin, 62: 1 - 39 .

[4] Ejedawe JE (1981). Patterns of incidence of oil reserves in Niger Delta Basin. American Association of Petroleum Geologist Bulletin. 1981;15741585.

[5] Knox, GJ and Omatsola, ME (1987). Development of the Cenozoic Niger Delta in terms of the escalator regression model. [In:] Proceedings of the KNGMG Symposium 'Coastal Lowlands - Geology and Geotechnology'. Kluwer Academic Publishers, 181-202. https://doi.org/10.1007/978-94017-1064-0 12.

[6] Stacher, P (1995). Present understanding of the Niger Delta hydrocarbon habitat. [In:] M.N. Oti \& G. Postma (Eds): Geology of deltas. Balkema, Rotterdam, 257-268.

[7] Reijers TJA (2011). Stratigraphy and sedimentology of the Niger Delta, Geologos, 2011, 17 (3): 133-162 https://doi.org/10.2478/v10118-0110008-3.

[8] Samuel O (2009). Integrated Evaluation of $\mathrm{CO}_{2}$ Risk in Niger Delta Reservoirs: A Critical Value Driver for HPHT Prospects SPDC internal unpublished report

[9] Oluwajana OA (2019). 2D seismic interpretation and evaluation of Middle Miocene source rocks within Agbada Formation, Coastal Swamp depobelt, Niger Delta Basin, Nigeria. Global Journal of Geological Science. 17(2): 97 - 103

[10] Olayiwola MA and Bamford MK (2016). Petroleum of the Deep: Palynological proxies for paleoenvironment of deep offshore upper MiocenePliocene sediments from Niger delta, Nigeria. Palaeontologia Africana, 50. 31-47

[11] Sneider RM, Tinker CN and Merkel LD (1978). Deltaic Environment, Reservoir Types and their Characteristics. Journal of Petroleum Technology, Nov. 1978, pp. 1538 - 1546. https://doi.org/10.2118/6701-PA.

[12] Beka FT and Oti MN (1995). “The Distal Offshore Niger Delta: Frontier Prospects of a Mature Petroleum Province,' In: M. N. Oti and G. Postma (Eds), Geology of Deltas (pp. 237 - 241) Rotterdam, A. A, Balkema press.

[13] Onyekuru SO, Ibelegbu EC, Iwuagwu JC, Essien AG and Akaolisa CZ (2012). Sequence stratigraphic analysis of "XB Field", Central Swamp Depobelt, Niger Delta Basin, Southern Nigeria. International Journal of Geoscience, 3, 237 - 257. https://doi.org/10.4236/ijg.2012.31027.

[14] Selley RC (1976). Subsurface Environmental Analysis of North Sea Sediments. AAPG Bulletin, Vol. 60, No. 2, 184 - 195. https://doi.org/10.1306/83D9229E-16C7-11D7-8645000102C1865D.

[15] Selley RC (1978). Concepts and Methods of Subsurface Facies Analysis. AAPG Education Course Notes. Series No. 9, 86. https://doi.org/10.1306/CE9397. 